\title{
Interaction of Human Dopa Decarboxylase with L-Dopa: Spectroscopic and Kinetic Studies as a Function of pH
}

\author{
Riccardo Montioli, Barbara Cellini, Mirco Dindo, Elisa Oppici, and Carla Borri Voltattorni
}

Section of Biological Chemistry, Department of Life Sciences and Reproduction, University of Verona, Strada Le Grazie 8, 37134 Verona, Italy

Correspondence should be addressed to Carla Borri Voltattorni; carla.borrivoltattorni@univr.it

Received 18 April 2013; Accepted 8 May 2013

Academic Editor: Alessandro Paiardini

Copyright (C) 2013 Riccardo Montioli et al. This is an open access article distributed under the Creative Commons Attribution License, which permits unrestricted use, distribution, and reproduction in any medium, provided the original work is properly cited.

\begin{abstract}
Human Dopa decarboxylase (hDDC), a pyridoxal 5' -phosphate (PLP) enzyme, displays maxima at 420 and $335 \mathrm{~nm}$ and emits fluorescence at 384 and $504 \mathrm{~nm}$ upon excitation at $335 \mathrm{~nm}$ and at $504 \mathrm{~nm}$ when excited at $420 \mathrm{~nm}$. Absorbance and fluorescence titrations of hDDC-bound coenzyme identify a single $\mathrm{pK}_{\text {spec }}$ of $\sim 7.2$. This $\mathrm{pK}_{\text {spec }}$ could not represent the ionization of a functional group on the Schiff base but that of an enzymic residue governing the equilibrium between the low- and the high-pH forms of the internal aldimine. During the reaction of hDDC with L-Dopa, monitored by stopped-flow spectrophotometry, a $420 \mathrm{~nm}$ band attributed to the $4^{\prime}$-N-protonated external aldimine first appears, and its decrease parallels the emergence of a $390 \mathrm{~nm}$ peak, assigned to the $4^{\prime}$-N-unprotonated external aldimine. The $\mathrm{pH}$ profile of the spectral change at $390 \mathrm{~nm}$ displays a $\mathrm{pK}$ of 6.4 , a value similar to that $(\sim 6.3)$ observed in both $k_{\text {cat }}$ and $k_{\text {cat }} / \mathrm{K}_{m}$ profiles. This suggests that this pK represents the $\mathrm{ESH}^{+} \rightarrow$ ES catalytic step. The assignment of the pKs of 7.9 and 8.3 observed on the basic side of $k_{\text {cat }}$ and the PLP binding affinity profiles, respectively, is also analyzed and discussed.
\end{abstract}

\section{Introduction}

Dopa decarboxylase (DDC; EC 4.1.1.28) is a pyridoxal $5^{\prime}$ phosphate- (PLP-) dependent enzyme which catalyzes the irreversible decarboxylation of L-Dopa and L-5-hydroxytryptophan (5-HTP), thus producing the neurotransmitters dopamine and serotonin. The enzyme accepts other catecholor indole-related L-amino acids and has been therefore also named L-aromatic amino acid decarboxylase (AADC). Like other PLP enzymes [1-7], DDC is of clinical interest since it is involved either in Parkinson's disease, a degenerative disorder of the central nervous system resulting from the death of dopamine-generating cells in the substantia nigra, or in AADC deficiency, a rare inherited neurometabolic disease due to mutations on the $A A D C$ gene leading to deficit of catecholamines and serotonin in the central nervous system and periphery [8]. Thus, the elucidation of the structural and functional features of the enzyme is relevant for the development of treatment strategies for both disorders. In this regard, a structure-based design search aimed at identifying inhibitors of peripheral DDC more selective than those currently administered to patients with Parkinson's disease has been recently reported [9]. Moreover, the molecular basis of AADC deficiency analyzed by comparing the characteristics of normal human DDC (hDDC) with those of some pathogenic variants in their recombinant purified form has allowed not only to unravel their molecular defects but also to suggest appropriate therapeutic treatments for patients bearing the examined mutations $[10,11]$.

Progress in understanding the structure/function relationships operating in DDC has been obtained by means of kinetic, spectroscopic, and structural studies on the pig kidney and rat liver enzymes, either in the naturally occurring [12-17] or in the recombinant purified [18-26] forms, as well as, more recently, on recombinant purified hDDC [9-11, 27]. The crystal structure of pig kidney holo DDC alone and in complex with carbidopa (a substrate analog endowed with a hydrazinic group) has been solved at 2.6 and $2.5 \AA$ resolutions, respectively [28]. The overall structure of the protein is a tightly associated dimer in which the active site is buried 
in the central part. Each monomer is composed of a large domain and a C-terminal domain, typical of the aspartate aminotransferase family (Fold Type I), as well as an Nterminal domain characteristic of Group II decarboxylases. Several other features of DDC are evident in these structures: (i) the way in which PLP is anchored to the enzyme involving His302 and His192, two highly conserved residues in $\alpha$ decarboxylases [29]; (ii) how the inhibitor binds; and (iii) which amino acid residues might be involved in the catalytic activity. Unexpectedly, the crystal structure of hDDC in the apo form reveals that it exists in an open conformation in which the dimer subunits move $20 \AA$ apart and the two active sites become solvent exposed. Moreover, by varying the PLP concentration in the crystals of the open DDC, two more structures have been solved, thus allowing to identify the structural determinants of the conformational change occurring upon PLP binding [27].

Although DDC enzymes share similar absorption spectra, that is, absorption maxima at 420 and $335 \mathrm{~nm}$, pig kidney and rat liver enzymes display different PLP emission fluorescent properties, possibly due to the presence, even if to a different degree, of a species absorbing at $335 \mathrm{~nm}$ and emitting fluorescence at $390 \mathrm{~nm}$ in their apoenzyme forms [15, 24, 25]. These findings, together with the fact that the coenzyme absorbing bands show a modest $\mathrm{pH}$ dependence, do not allow to unequivocally assign the $335 \mathrm{~nm}$ absorbing band to a form of the internal aldimine and to understand how the equilibrium between the 420 and $335 \mathrm{~nm}$ species is governed. Moreover, although previous spectroscopic analyses of the reaction of both pig kidney and rat liver DDC with L-Dopa provided evidence for the appearance of two intermediates absorbing at 420 and $385 \mathrm{~nm}$, the assignment of these species is conflicting. These absorbance bands have been attributed to $1-\mathrm{N}$-protonated- $4^{\prime}-\mathrm{N}$-protonated and $1-\mathrm{N}$-protonated- $4^{\prime}$ $\mathrm{N}$-unprotonated Schiff bases shown by the low- and high-pH forms of the external aldimine $[13,17]$. On the other hand, other authors suggested that these species were formed during the course of the decarboxylation reaction, being the $420 \mathrm{~nm}$ and the $385 \mathrm{~nm}$ either the adsorption complex and the external aldimine with L-Dopa, respectively $[25,26]$, or two different external aldimines [30].

The present study presents a detailed investigation of the $\mathrm{pH}$ dependence of the bound coenzyme absorbance and fluorescence features and of the steady-state kinetic parameters of hDDC. Additionally, changes of the absorbance bands of hDDC upon L-Dopa binding as a function of $\mathrm{pH}$ have been monitored by rapid scanning stopped-flow experiments. Taken together, the results allow us to identify three observable ionizations in hDDC and to propose their involvement in the structures of the bound coenzyme and in the intermediates along the decarboxylation pathway.

\section{Material and Methods}

2.1. Chemicals. L-Dopa, PLP, 2,4,6-trinitrobenzene-1-sulfonic acid, isopropyl- $\beta$-D-thiogalactopyranoside, and protease inhibitor cocktail were purchased from Sigma-Aldrich. BisTris-propane at a final concentration of $50 \mathrm{mM}$ was used over the $\mathrm{pH}$ range $6-8.8$. The other chemicals were of the highest purity available.

2.2. Enzyme Preparation. The conditions used for expression and purification of hDDC were as previously described [11]. The apo form was prepared as previously reported [11].

2.3. Binding Affinity of $h D D C$ for PLP. The equilibrium dissociation constant for PLP, $\mathrm{K}_{\mathrm{D}(\mathrm{PLP})}$, was determined by measuring the quenching of the intrinsic fluorescence of the apoenzyme $(0.15 \mu \mathrm{M})$ in the presence of PLP at a concentration range of $0.01-20 \mu \mathrm{M}$. The experiments were carried out in $50 \mathrm{mM}$ Bis-Tris-propane in the $\mathrm{pH}$ range 68.8. The $\mathrm{K}_{\mathrm{D} \text { (PLP) }}$ values were obtained by fitting the data to the following equation:

$$
Y=Y_{\mathrm{MAX}} \frac{[E]_{t}+[\mathrm{PLP}]_{t}+\mathrm{K}_{\mathrm{D}(\mathrm{PLP})}-\sqrt{\left([E]_{t}+[\mathrm{PLP}]_{t}+\mathrm{K}_{\mathrm{D}(\mathrm{PLP})}\right)^{2}-4[E]_{t}[\mathrm{PLP}]_{t}}}{2[E]_{t}},
$$

where $[E]_{t}$ and $[\mathrm{PLP}]_{t}$ represent the total concentrations of hDDC dimer and PLP, respectively, $Y$ refers to the intrinsic fluorescence quenching changes at a PLP concentration, [PLP], and $Y_{\max }$ refers to the aforementioned changes when all enzyme molecules are complexed with the coenzyme.

2.4. Enzyme Assay. The decarboxylase activity toward LDopa was measured by the spectrophotometric assay described by Sherald et al. [31], and it was modified by Charteris and John [32]. Measurements were performed in the presence of $10 \mu \mathrm{M}$ PLP. Data of enzymatic activity as a function of substrate concentration were fitted to Michaelis-Menten equation.

2.5. Spectral Measurements. Absorption spectra were made with a Jasco V-550 spectrophotometer at a protein concentration of $10 \mu \mathrm{M}$. Fluorescence spectra were taken with an FP750 Jasco spectrofluorometer using $5 \mathrm{~nm}$ excitation and emission bandwidths at a protein concentration of $10 \mu \mathrm{M}$. The enzyme solution was drawn through a $0.2 \mu \mathrm{m}$ filter to reduce light scattering from the small amount of precipitate. Spectra of blanks, that is, samples containing all components except hDDC, were taken immediately before the measurements of samples containing protein.

2.6. pH Studies. Absorbance and fluorescence data were fitted to (2) and (3):

$$
\begin{aligned}
& A=\frac{A_{1}-A_{2}}{1+10^{\mathrm{pH}^{\mathrm{pK}} \mathrm{spec}}}+A_{2}, \\
& A=\frac{A_{1}-A_{2}}{1+10^{\mathrm{pK}_{\text {spec }}-\mathrm{pH}}}+A_{2},
\end{aligned}
$$

where $A_{1}$ and $A_{2}$ are the higher and the lower absorbance limits at a particular wavelength, respectively. 
The $\log \mathrm{K}_{\mathrm{D} \text { (PLP) }}, \log k_{\text {cat }}, \log k_{\text {cat }} / \mathrm{K}_{m}$, and values for $\mathrm{hDDC}$ versus $\mathrm{pH}$ were fitted to the following appropriate equations:

$$
\begin{gathered}
\log Y=\log \frac{Y_{L}+Y_{H}\left(H / \mathrm{K}_{1}\right)}{1+H / \mathrm{K}_{1}}, \\
\log Y=\log \frac{C}{1+H / \mathrm{K}_{A}+\mathrm{K}_{B} / H}, \\
\log Y=\log \frac{C}{1+H / \mathrm{K}_{A}},
\end{gathered}
$$

where $K_{A}$ and $K_{B}$ represent the ionization constants for enzyme or reactant functional groups, $Y$ is the value of the parameter observed as a function of $\mathrm{pH}, \mathrm{C}$ is the $\mathrm{pH}$-independent value of $Y, H$ is the hydrogen ion concentration, and $Y_{L}$ and $Y_{H}$ are constant values at low and high $\mathrm{pH}$, respectively.

2.7. Pre-Steady-State Kinetic Analysis by UV-Vis Stopped-Flow Spectroscopy. hDDC was mixed using a Biologic SFM300 mixer with an equal volume of $2 \mathrm{mM}$ L-Dopa in $50 \mathrm{mM}$ BisTris-propane at $\mathrm{pH}$ ranging from 6.0 to 8.0. Coenzyme absorbance changes were monitored with a TC-100 (path length of $1 \mathrm{~cm}$ ) quartz cell coupled to a Biokine PMS-60 instrument. The dead time was $3.8 \mathrm{~ms}$ at a flow velocity of $8 \mathrm{~mL} / \mathrm{sec}$. Absorbance scans (800) from 300 to $600 \mathrm{~nm}$ were collected on a logarithmic time scale with a J\&M Tidas 16256 diode array detector (Molecular kinetics, Pullman, WA). Data were analyzed using either SPECFIT (Spectrum Software, Claix, France) or Biokine 4.01 (Biologic, Claix, France) to determine the observed rate constants. Single-wavelength time courses were fit to an equation of the following general form:

$$
A_{t}=A_{\infty} \pm \sum A_{i} \exp ^{\left(-k_{\mathrm{obs}} t\right)},
$$

where $A_{t}$ is the absorbance at time $t, A_{i}$ is the amplitude of each phase, $k_{\text {obs }}$ is the observed rate constant for each phase, and $A_{\infty}$ is the final absorbance.

\section{Results}

3.1. pH Dependence of the Internal Aldimine and Coenzyme Binding Affinity. Apo hDDC completely lacks absorbance in the visible region, while the holo form is characterized by absorbance bands at 420 and $335 \mathrm{~nm}$ associated with positive dichroic signals at the same wavelengths [11]. The absorbance spectrum of hDDC in the holo form changes as a function of $\mathrm{pH}$ over the range 6-8.5 (Figure 1): the $335 \mathrm{~nm}$ band increases with $\mathrm{pH}$, while the $420 \mathrm{~nm}$ band decreases. The spectra do not show a clear isosbestic point, thus suggesting the presence of multiple species. When we fitted the data to curves with one, two, or three ionizations, we found that they fit best to a model with one ionization ((2) and (3)): the $\mathrm{pK}_{\text {spec }}$ values obtained were $7.2 \pm 0.1$ and $7.3 \pm 0.1$ for the absorbance at 420 and $335 \mathrm{~nm}$, respectively (Figure 1, inset) (Table 1).

Excitation of hDDC at $420 \mathrm{~nm}$ results in an emission band at $504 \mathrm{~nm}$, whose intensity decreases as $\mathrm{pH}$ increases below

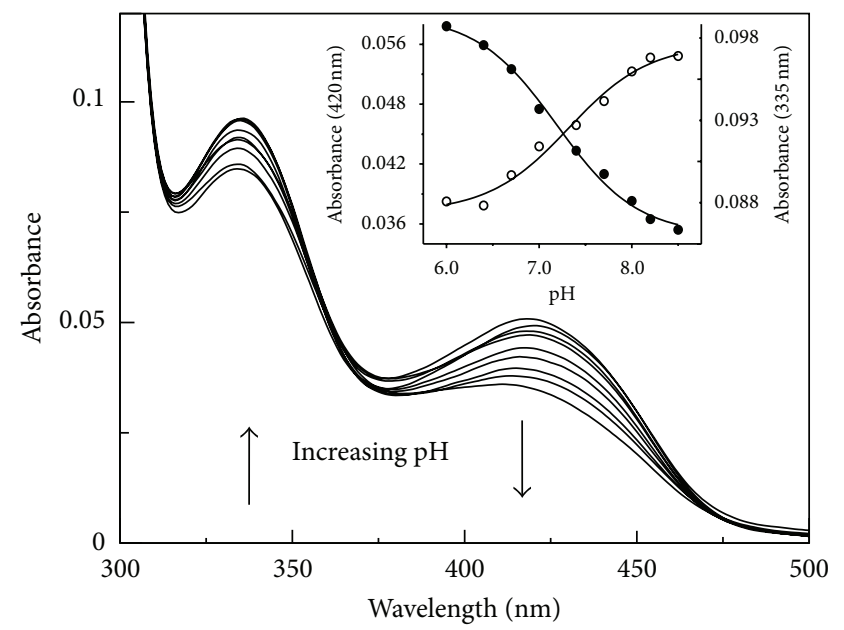

FIgURE 1: $\mathrm{pH}$ dependence of the visible spectra of hDDC. Absorbance spectra of $10 \mu \mathrm{M}$ hDDC were acquired in $50 \mathrm{mM}$ BisTris-propane at $\mathrm{pH}$ 6.0, 6.4, 7.0, 7.4, 7.7, 8.0, 8.2, and 8.5. The inset shows the $\mathrm{pH}$ dependence of the absorbance at $420(\bullet)$ and $335 \mathrm{~nm}$

\begin{tabular}{|c|c|c|c|}
\hline Parameter & $\begin{array}{l}\mathrm{pH} \text {-independent } \\
\text { value }\end{array}$ & $\mathrm{pK}_{1}$ & $\mathrm{pK}_{2}$ \\
\hline$\overline{k_{\text {cat }}}$ & $5.1 \pm 0.4 \mathrm{~s}^{-1}$ & $6.3 \pm 0.1$ & $7.9 \pm 0.1$ \\
\hline$k_{\text {cat }} / K_{m}$ & $174 \pm 3 \mathrm{mM}^{-1} \mathrm{~s}^{-1}$ & $6.1 \pm 0.1$ & \\
\hline $\begin{array}{l}\text { Absorbance at } 420 \mathrm{~nm} \mathrm{pH} \\
\text { titration }\end{array}$ & & & $7.2 \pm 0.1$ \\
\hline $\begin{array}{l}\text { Absorbance at } 335 \mathrm{~nm} \mathrm{pH} \\
\text { titration }\end{array}$ & & & $7.3 \pm 0.1$ \\
\hline \multicolumn{4}{|l|}{$\begin{array}{l}\text { Emission fluorescence } \mathrm{pH} \\
\text { titration (exc. } 335 \mathrm{~nm} \text { ) }\end{array}$} \\
\hline emis. $_{384 \mathrm{~nm}}$ & & & $7.3 \pm 0.1$ \\
\hline emis. $_{504 \mathrm{~nm}}$ & & & $7.2 \pm 0.1$ \\
\hline \multicolumn{4}{|l|}{$\begin{array}{l}\text { Emission fluorescence pH } \\
\text { titration (exc. } 420 \mathrm{~nm} \text { ) }\end{array}$} \\
\hline emis. $504 \mathrm{~nm}$ & & & $7.2 \pm 0.1$ \\
\hline Amplitude ext. ald. $390 \mathrm{~nm}$ & & $6.4 \pm 0.3$ & \\
\hline $\mathrm{K}_{\mathrm{D}(\mathrm{PLP})}$ & & & $8.3 \pm 0.2$ \\
\hline
\end{tabular}
(o). The solid lines represent the theoretical curves according to (2) and (3).

TABLE 1: Summary of $\mathrm{pK}_{\mathrm{a}}$ values for hDDC.

a single pK of $7.2 \pm 0.1$ (Figure 2(a) and inset). Moreover, $\mathrm{hDDC}$ emits at 384 and $504 \mathrm{~nm}$ upon excitation at $335 \mathrm{~nm}$. Emission fluorescence intensity at $384 \mathrm{~nm}$ increases with increasing $\mathrm{pH}$, while that at $504 \mathrm{~nm}$ decreases (Figure 2(b)). As shown in the inset of Figure 2(b), the $\mathrm{pH}$ profile for the $384 \mathrm{~nm}$ emission intensity increases above a single $\mathrm{pK}$ of $7.3 \pm 0.1$, while that at $504 \mathrm{~nm}$ decreases below a single pK of $7.1 \pm 0.1$ (Table 1). When emission was observed at $384 \mathrm{~nm}$, the excitation spectrum exhibits a maximum at $337 \mathrm{~nm}$, whereas at $500 \mathrm{~nm}$, the excitation spectrum displays maxima at 341 and $410 \mathrm{~nm}$.

The $\mathrm{K}_{\mathrm{D}(\mathrm{PLP})}$ value for hDDC at $\mathrm{pH} 7.4$ is $0.2 \mu \mathrm{M}$, and it increases as the $\mathrm{pH}$ increases. The $\mathrm{pH}$ dependence of $\mathrm{K}_{\mathrm{D}(\mathrm{PLP})}$ 


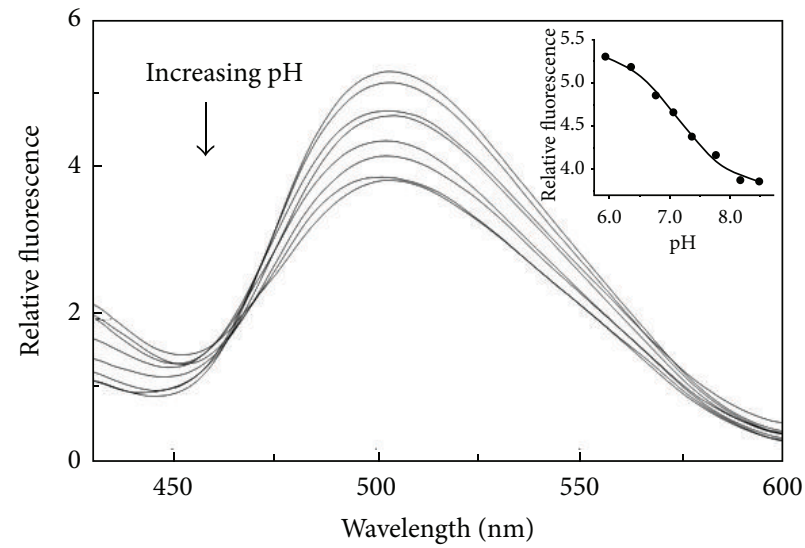

(a)

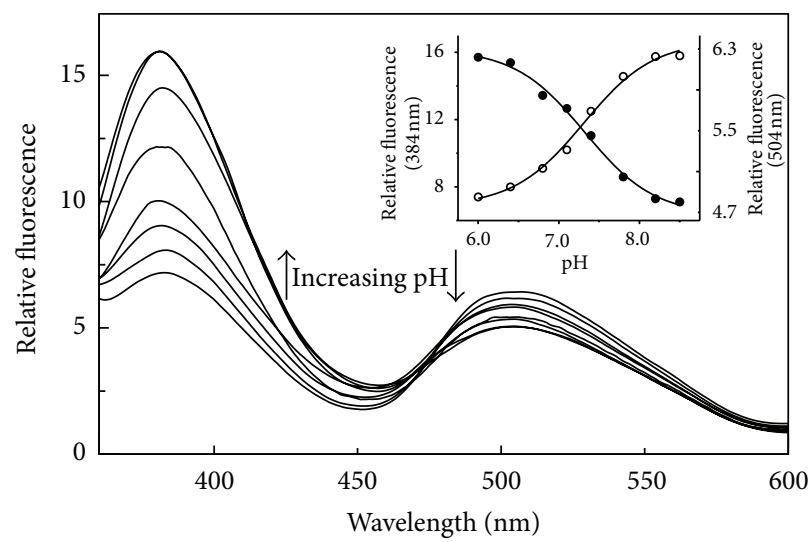

(b)

FIGURE 2: $\mathrm{pH}$ dependence of the internal aldimine emission fluorescence of hDDC. Emission fluorescence spectra of $10 \mu \mathrm{M}$ hDDC in $50 \mathrm{mM}$ Bis-Tris-propane at $\mathrm{pH} 6.0,6.4,6.8,7.1,7.4,7.8,8.2$, and 8.5 upon excitation at $420 \mathrm{~nm}$ (a) and $335 \mathrm{~nm}$ (b). The inset of (a) shows the pH dependence of the emission intensity at $504 \mathrm{~nm}(\bullet)$, while that of (b) shows the $\mathrm{pH}$ dependence of the emission intensity at $504 \mathrm{~nm}(\circ)$ and $384 \mathrm{~nm}(\bullet)$. The solid lines represent the theoretical curves according to (2) and (3).

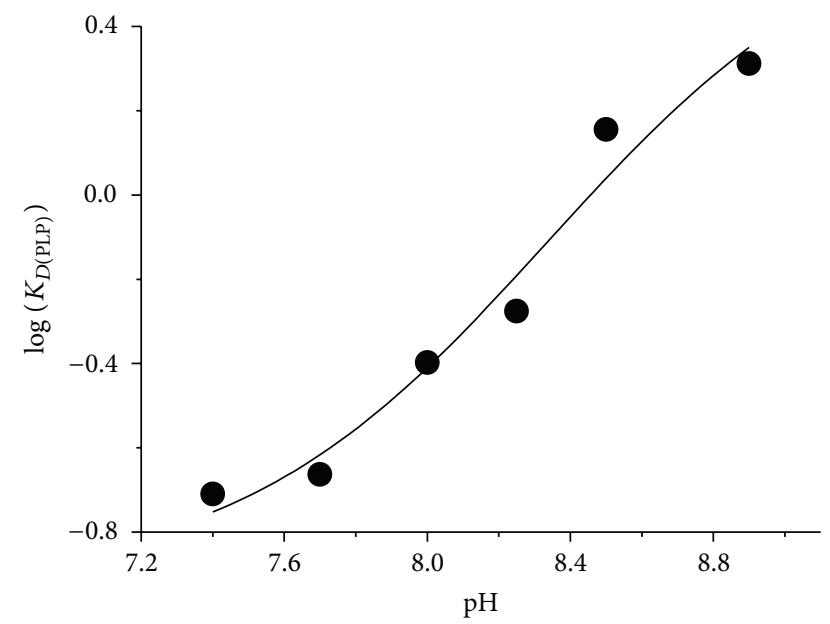

Figure 3: $\mathrm{pH}$ dependence of $\mathrm{K}_{\mathrm{D}(\mathrm{PLP})}$ of hDDC. $\mathrm{K}_{\mathrm{D}(\mathrm{PLP})}$ values were determined in $50 \mathrm{mM}$ Bis-Tris-propane at the indicated $\mathrm{pH}$ as described under "Section 2". The points shown are the experimental values (expressed in $\mu \mathrm{M}$ ), while the curve is from fit to the data using (4).

fits well (4), giving a $\mathrm{pK}_{\mathrm{D}(\mathrm{PLP})}$ value of $8.3 \pm 0.2$ (Figure 3, Table 1).

3.2. $p H$ Dependence of Kinetic Parameters for hDDC. The $\mathrm{pH}$ dependence of the kinetic parameters for hDDC toward L-Dopa was determined, and the results are shown in Figures 4(a) and 4(b). The variation with $\mathrm{pH}$ of $\log k_{\mathrm{cat}}$ gives rise to a bell-shaped profile: fitting the data to (5) and (6) yields $\mathrm{pK}$ values of $6.3 \pm 0.1$ and $7.9 \pm 0.1 ; \log k_{\text {cat }} / \mathrm{K}_{m}$ decreases below a $\mathrm{pK}$ of $6.1 \pm 0.1$ (Table 1).

3.3. $p H$ Dependence of External Aldimine with L-Dopa. To obtain information about the identity of intermediates in the reaction of hDDC with L-Dopa we carried out rapid-kinetic spectroscopic studies over the $\mathrm{pH}$ range 6-8. Upon mixing the enzyme with L-Dopa at a saturating concentration, a biphasic spectral change was observed. In the first phase, a rapid increase in the absorbance at $420 \mathrm{~nm}$ and a decrease in the $335 \mathrm{~nm}$ band were observed within $50 \mathrm{~ms}$, followed by a second phase, in which the absorbance at $420 \mathrm{~nm}$ decreases and concomitantly a new absorbance band appears at 390, occurring with a rate of $31 \mathrm{~s}^{-1}$ (Figure 5). The amplitude of the absorbance changes at $390 \mathrm{~nm}$ increases with $\mathrm{pH}$ above a single $\mathrm{pK}$ of $6.4 \pm 0.3$ (Figure 6) (Table 1). It should be also noted that at $\mathrm{pH}$ higher than 6.4 the appearance of the $390 \mathrm{~nm}$ band is accompanied by that of a shoulder absorbing at $\sim 440 \mathrm{~nm}$. Considering that the enzyme-dopamine complex absorbs at $\sim 400 \mathrm{~nm}$ and that only a modest amount of dopamine $(20 \mu \mathrm{M})$ is formed at the end of the second phase, the shoulder cannot be attributed to the enzyme-dopamine complex. A likely attribution might be a quinonoid species, which, according to Metzler et al. [33], could absorb at wavelengths lower than $500 \mathrm{~nm}$.

In order to establish if the intermediate absorbing at $420 \mathrm{~nm}$ represents a Michaelis complex or an external aldimine, its rate of formation as a function of L-Dopa concentration was measured. We decided to carry out these measurements at $15^{\circ} \mathrm{C}$ and at $\mathrm{pH} 6.0$, that is, under experimental conditions in which the decarboxylation reaction is slow enough so that its kinetics can be measured. As shown in Figure 7, upon addition of L-Dopa to hDDC, an increase in the $420 \mathrm{~nm}$ band with a concomitant decrease in the $335 \mathrm{~nm}$ signal can be seen. The apparent first-order rate constant of the appearance of the $420 \mathrm{~nm}$ band, $k_{\text {obs }}$, shows a hyperbolic dependence on L-Dopa concentration in the range 0.08$1 \mathrm{mM}$ (inset of Figure 7). The $k_{\mathrm{obs}}$ data were fitted to the following equation:

$$
k_{\mathrm{obs}}=k_{+2} \frac{[\mathrm{L}-\mathrm{Dopa}]}{K_{1}+[\mathrm{L}-\mathrm{dopa}]}+k_{-2} \text {, }
$$






(a)

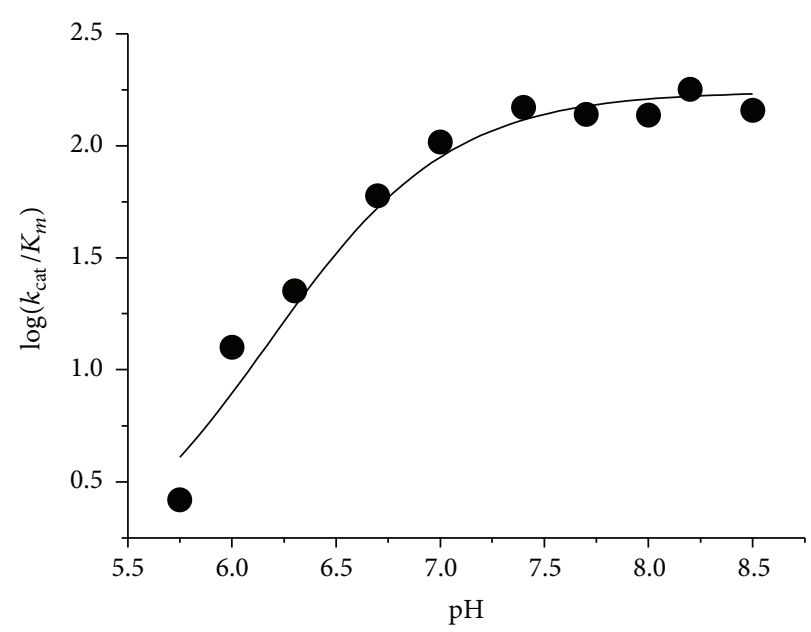

(b)

FIGURE 4: $\mathrm{pH}$ dependence of the kinetic parameters for the decarboxylase activity of hDDC toward L-Dopa. (a) Log $k_{\text {cat }}$ profile and (b) log $k_{\text {cat }} / \mathrm{K}_{m}$ profile. The assays were performed at $25^{\circ} \mathrm{C}$ in $50 \mathrm{mM}$ Bis-Tris-propane at the indicated $\mathrm{pH}$ using $50 \mathrm{nM}$ enzyme concentration in the presence of $10 \mu \mathrm{M}$ exogenous PLP. The points shown are the experimental values, while the curves are from fits to the data using (5) for log $k_{\text {cat }}$ and (6) for $\log k_{\text {cat }} / K_{m}$.

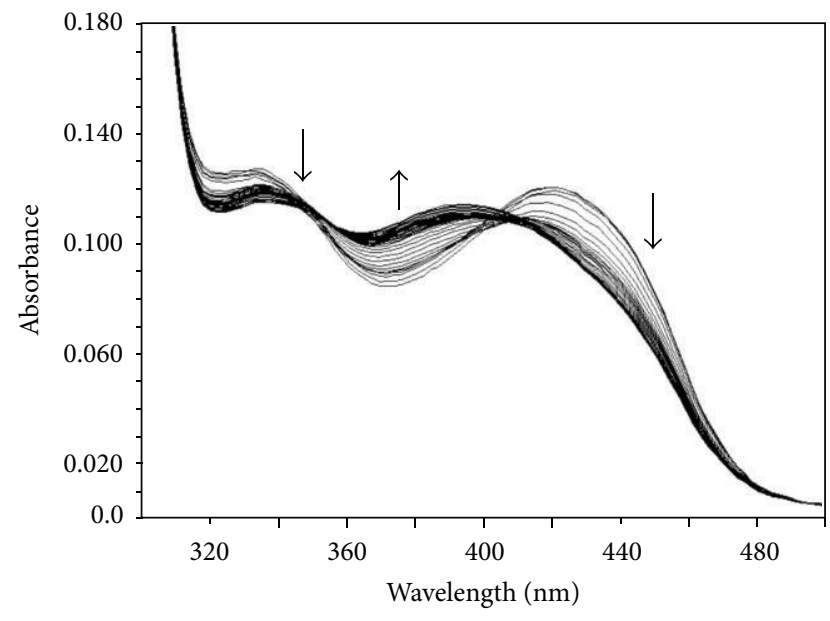

FIGURE 5: Time-resolved spectra for the reaction of hDDC with LDopa. Rapid scanning stopped-flow spectra obtained upon reaction of hDDC $(20 \mu \mathrm{M})$ with L-Dopa $(2 \mathrm{mM})$ in Tris-Bis-propane, $\mathrm{pH} 7.4$, at $25^{\circ} \mathrm{C}$. Spectra were taken between 1 and $100 \mathrm{~ms}$ at $1 \mathrm{~ms}$ intervals and between 101 and $200 \mathrm{~ms}$ at $10 \mathrm{~ms}$ intervals.

which describes the following two-step binding model assuming that the first step is rapid:

$$
\begin{aligned}
& \text { E }+ \text { L-Dopa } \stackrel{K_{1}}{\rightleftarrows} \text { E-L-Dopa intermediate } \\
& \underset{k_{-2}}{\stackrel{k_{+2}}{\rightleftarrows} \text { E-L-Dopa Schiff base, }}
\end{aligned}
$$

where $K_{1}$ is the dissociation constant for the intermediate (Michaelis complex or geminal diamine) formed prior to the formation of the Schiff base species, and $k_{+2}$ and $k_{-2}$ are firstorder rate constants for an interconversion between the intermediate and the Schiff base. Estimated values of $k_{+2}$ and

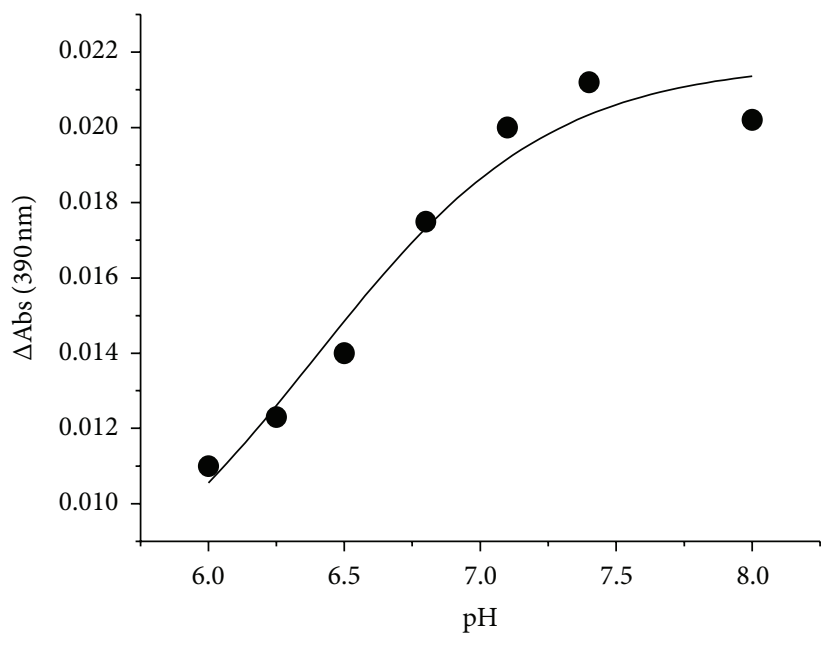

FIGURE 6: $\mathrm{pH}$ dependence of the amplitude of the change of the $390 \mathrm{~nm}$ absorbance band in the reaction of hDDC with L-Dopa. Amplitude of the $390 \mathrm{~nm}$ absorbance band monitored by rapid scanning stopped-flow spectra upon reaction of hDDC $(20 \mu \mathrm{M})$ and L-Dopa $(2 \mathrm{mM})$ in Tris-Bis-propane, at $25^{\circ} \mathrm{C}$ at the indicated $\mathrm{pH}$. The points shown are the experimental values, while the curve is from fit to the data using (3).

$K_{1}$ based on the data in the inset of Figure 7 are $124 \pm 3 \mathrm{~s}^{-1}$ and $0.32 \pm 0.02 \mathrm{mM}$, respectively, while the $k_{-2}$ value is nearly zero. The $K_{1}$ value is consistent with the $\mathrm{K}_{m}$ value at $\mathrm{pH} 6.0$ $(0.23 \pm 0.03 \mathrm{mM})$ measured under steady-state conditions, thus strongly suggesting that the intermediate absorbing at $420 \mathrm{~nm}$ represents a $1-\mathrm{N}-4^{\prime}-\mathrm{N}$-protonated external aldimine. It follows that the rate of formation of the Schiff base at $25^{\circ} \mathrm{C}$ can be estimated to be around $250 \mathrm{~s}^{-1}$ using the empirical rule of a 2 -fold reduction for a $10^{\circ} \mathrm{C}$ reduction in temperature. This value is considerably higher $\left(\sim 80\right.$-fold) than the $k_{\text {cat }}$ 


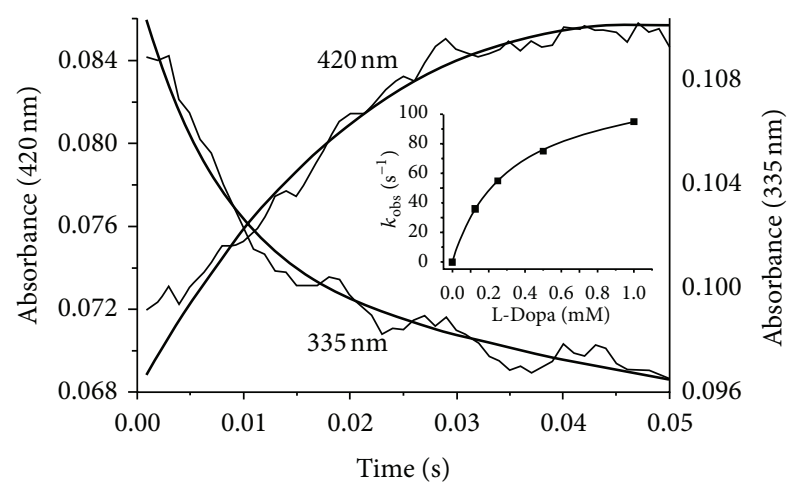

Figure 7: Single-wavelength stopped-flow measurements of the reaction of hDDC with L-Dopa at $\mathrm{pH} 6.0$ and $15^{\circ} \mathrm{C}$. Reaction of hDDC $(20 \mu \mathrm{M})$ with L-Dopa $(1 \mathrm{mM})$ was carried out at $15^{\circ} \mathrm{C}$ in $50 \mathrm{mM}$ Bis-Tris-propane ( $\mathrm{pH}$ 6.0). Time courses at 420 and $335 \mathrm{~nm}$ are reported. The solid lines are from fits to (7). The inset shows the dependence of $k_{\text {obs }}$ for the increase in the intensity of the $420 \mathrm{~nm}$ band as a function of the final concentrations of L-Dopa after mixing. The points shown are the experimental values, while the curve is from fit to the data using (8).

value at $25^{\circ} \mathrm{C}$ at $\mathrm{pH} 6.0\left(3 \mathrm{~s}^{-1}\right)$, thus indicating that one of the catalytic steps after the external Schiff base formation, including the decarboxylation step, is rate determining in the entire catalytic reaction [34]. All together, these data indicate the consecutive formation of two external aldimines, one absorbing at $420 \mathrm{~nm}$ and the other at $390 \mathrm{~nm}$, whose structures are presented in Figure 8.

\section{Discussion}

The $\mathrm{pH}$ dependence of catalysis and spectral features has been studied in details for only a few PLP-dependent enzymes [3539]. This allowed to elucidate how ionizations control their activities. Up to date, such analyses have been hampered for DDC for the following reasons: (i) a large portion of the coenzyme covalently bound is present in both pig kidney and rat liver enzymes in an inactive form and shows absorbance and PLP emission fluorescence similar to those of the corresponding holoenzymes and (ii) both pig kidney and rat liver DDC enzymes show little absorbance changes with altering $\mathrm{pH}$.

Unlike the apo form of pig kidney and rat liver DDC, the apo hDDC does not display any absorbance in the $330 \mathrm{~nm}$ region and does not exhibit PLP emission fluorescence. Thus, we decided to perform a detailed investigation of the $\mathrm{pH}$ dependence of the spectroscopic properties of hDDC in its internal and external aldimine forms, of the PLP binding affinity as well as of the steady-state kinetic parameters. The following discussion attempts to assign the $\mathrm{pK}$ values observed in these analyses.

The titration of hDDC-bound coenzyme absorbance and fluorescence over the $\mathrm{pH}$ range 6-8.5 is consistent with a deprotonation event with a pKa value of $\sim 7.3$, which could be the result of the deprotonation of the internal aldimine. However, there is no red shift in the $335 \mathrm{~nm}$ band at $\mathrm{pH}$ values higher than the apparent $\mathrm{pK}$, as would be expected for the unprotonated aldimine absorbing at $360 \mathrm{~nm}$. Structures which could account for an increase in the $330 \mathrm{~nm}$ region at high $\mathrm{pH}$ have been postulated to arise either from the formation of an adduct upon addition of a deprotonated nucleophilic or a hydroxyl group to the imine double bond or from the conversion from the ketoenamine to the enolimine tautomer. The attribution of the $335 \mathrm{~nm}$ absorbance band to a substituted aldamine is in contrast with the following data: (i) when hDDC is treated with $\mathrm{NH}_{2} \mathrm{OH}$, the absorbance bands at 420 and $335 \mathrm{~nm}$ are completely lost, and the resultant apoenzyme lacks the PLP emission fluorescence, (ii) binding of L-Dopa causes the disappearance of the 335 absorbance band, (iii) upon excitation at $335 \mathrm{~nm}$, the $384 \mathrm{~nm}$ fluorescence emission remains at low $\mathrm{pH}$ where the substituted aldamine would be destabilized by protonation, and (iv) the fluorescence excitation spectrum at the emission wavelength of $384 \mathrm{~nm}$ shows that the absorbance band that gives the excited state is seen at $341 \mathrm{~nm}$, which is apparently longer than the wavelength generally observed for substituted aldamine structures, $330-335 \mathrm{~nm}$. Thus, it should be taken in consideration the possibility that the $335 \mathrm{~nm}$ band could be attributed to the enolimine tautomer of the Schiff base. Both 384 and $504 \mathrm{~nm}$ emission maxima are seen upon excitation of hDDC at $335 \mathrm{~nm}$, and acid promotes the $504 \mathrm{~nm}$ emission at the expense of the $384 \mathrm{~nm}$ emission. Honikel and Madsen have shown that the enolimine can emit either solely at 400 or $\sim 500 \mathrm{~nm}$, or at a combination of both wavelengths, depending on the polarity and acidity of the solvent. Fluorescence emission at $\sim 400 \mathrm{~nm}$ versus $500 \mathrm{~nm}$ is determined by a competition between (i) proton transfer from the enolimine structure at the excited state to the aldimine nitrogen of the ketoenamine in the singlet excited state and (ii) radiative decay of the excited to the ground state [40]. On the basis of all these considerations, we can conclude that the $384 \mathrm{~nm}$ fluorescence emission of hDDC results from the excited state of the enolimine tautomer of the Schiff base before it has tautomerized to the ketoenamine excited state. A similar explanation has been proposed for the $\mathrm{pH}$-dependent spectral changes observed for dialkylglycine decarboxylase [37], serine glyoxylate aminotransferase [38], histidine decarboxylase [41], and glutamate decarboxylase [42]. Examination of the absorbance titration curves indicates that at $\mathrm{pH}$ values much lower than the apparent $\mathrm{pK}(\sim 7.2)$ some $335 \mathrm{~nm}$ is still present and that at $\mathrm{pH}$ values higher than $\mathrm{pK}$ some $420 \mathrm{~nm}$ absorbing species remains. Thus, one might expect from our results that the pyridine nitrogen in hDDC is not fully protonated, as it is usually assumed for PLP enzymes having an aspartate residue interacting with the pyridine nitrogen. Accordingly, the model depicted in Scheme 1 is proposed: the $\mathrm{N}$-protonated (I) and N-unprotonated (II) ketoenamine forms absorb at $420 \mathrm{~nm}$, while the N-protonated (III) and $\mathrm{N}$-unprotonated (IV) enolimine tautomers absorb at $335 \mathrm{~nm}$. At $\mathrm{pH}$ values less than $\mathrm{pK}$ I and III will be present, while II and IV represent the forms at $\mathrm{pH}$ much higher than the $\mathrm{pK}$. Ring nitrogen protonation state governs the two equilibria between I and II absorbing at $420 \mathrm{~nm}$ as well as between III and IV absorbing at $335 \mathrm{~nm}$, that is, between species spectroscopically indistinguishable. Thus, the most likely 
<smiles></smiles>

$420 \mathrm{~nm}$
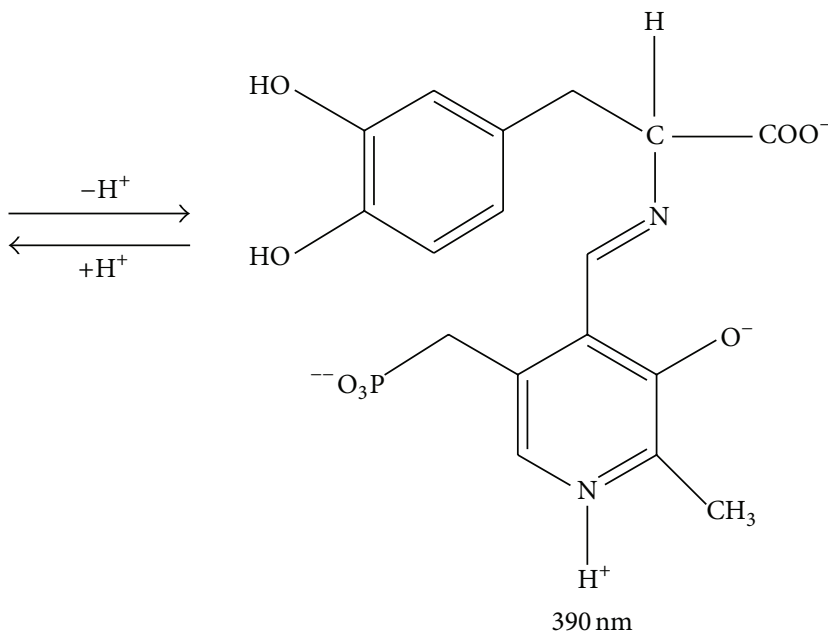

Figure 8: Structures of the coenzyme-L-Dopa complexes absorbing at $420 \mathrm{~nm}$ and $390 \mathrm{~nm}$.

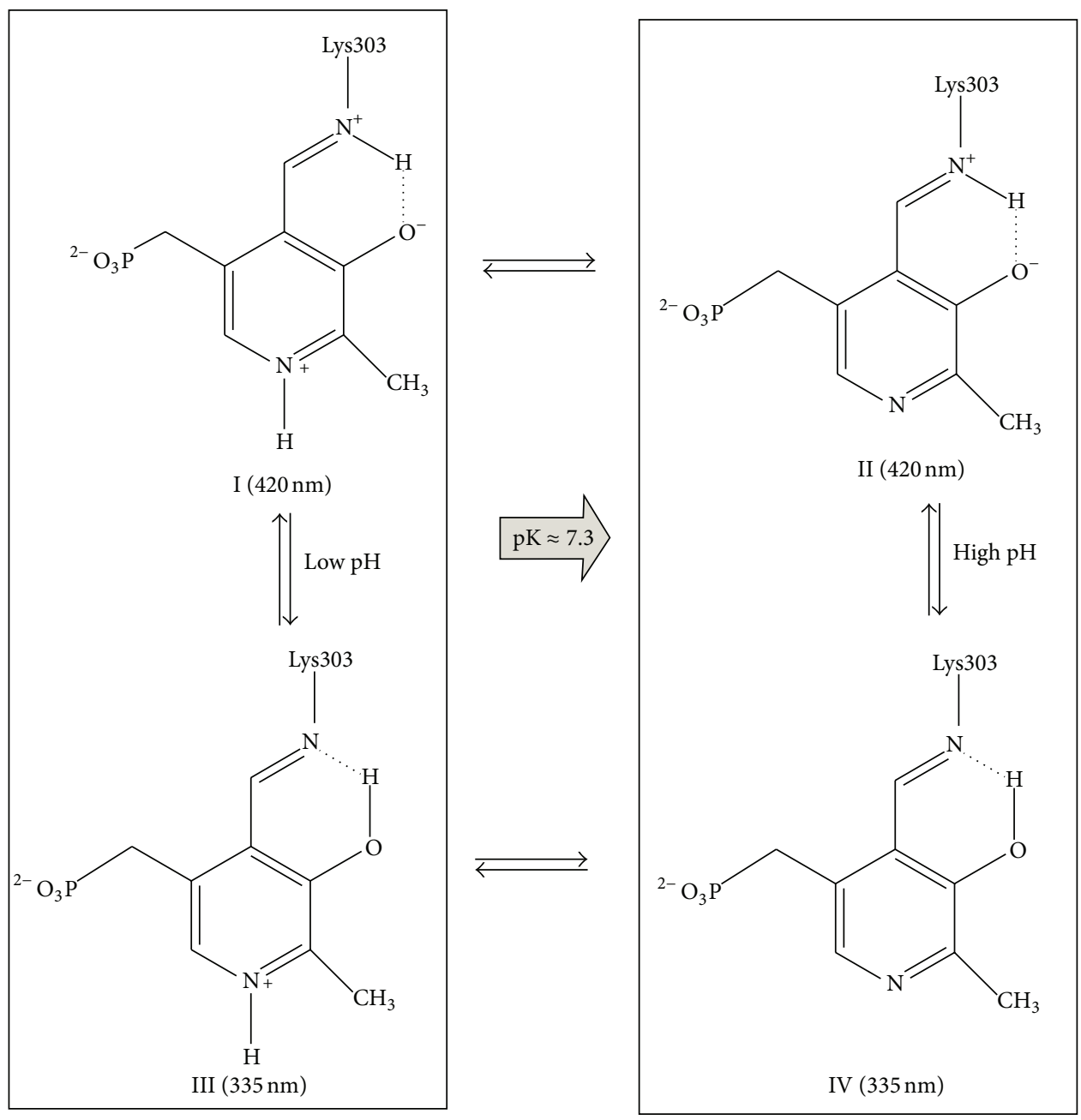

Scheme 1: Putative model for the $\mathrm{pH}$ dependence of the internal aldimine. 
explanation that accounts for the $\mathrm{pH}$ titration of coenzyme absorbance and fluorescence is that the ionization observed is not associated with any functional group on the Schiff base itself. Rather, it is an active site residue in close proximity to the coenzyme whose ionization alters the ratio between the two tautomers that absorb at 420 and $335 \mathrm{~nm}$.

The $k_{\text {cat }}$ profile of the decarboxylation reaction catalyzed by hDDC toward L-Dopa displays two $\mathrm{pKa}$ values at about 6.3 and 7.9, thus suggesting that one group is required to be unprotonated and a second group protonated to achieve maximum velocity. The $\mathrm{pKa}$ on the acidic side of the profile is similar to that seen in the $k_{\text {cat }} / \mathrm{K}_{m}$ profile, and, thus, it can be concluded that this group is involved in catalysis but not in binding. Since it has been proven that in pig kidney $\mathrm{DDC} \mathrm{CO}_{2}$ release is rate limiting, $k_{\text {cat }}$ must report on ionization(s) of the external aldimine. Thus, the spectral changes taking place in the bound coenzyme upon addition of L-Dopa have been analyzed as a function of $\mathrm{pH}$ by rapid scanning stopped-flow spectroscopy. The kinetic analyses of the reaction of hDDC with L-Dopa clearly demonstrate the presence of two intermediates absorbing at 420 and $390 \mathrm{~nm}$. The $420 \mathrm{~nm}$ absorbing species is formed first, followed by formation of the second intermediate absorbing at $390 \mathrm{~nm}$. The amplitude of the signal change at $390 \mathrm{~nm}$ increases with increasing $\mathrm{pH}$ above a single $\mathrm{pK}$ of $\sim 6.4$. The finding that the rate of appearance of the $420 \mathrm{~nm}$ band measured at $\mathrm{pH} 6.0$ shows that a hyperbolic dependence on the concentration of L-Dopa is consistent with the assignment of this absorbance band to a $4^{\prime}$-N-protonated external aldimine. The time and $\mathrm{pH}$ dependence of the conversion of the 420 to the $390 \mathrm{~nm}$ absorbance band strongly suggest that the $390 \mathrm{~nm}$ band could be attributed to a $4^{\prime}$-N-unprotonated external aldimine. Even in the absence of the spectra of these intermediates, Minelli et al. [30] have predicted the presence of the step $\mathrm{ESH}^{+} \rightarrow$ ES, corresponding to the $420 \rightarrow 390 \mathrm{~nm}$ conversion, along the reaction pathway of the decarboxylation of L-Dopa. Our results validate this proposal, thus ruling out that the $420 \mathrm{~nm}$ intermediate represents Michaelis complex, as previously suggested $[25,26]$. The $\mathrm{pK}$ of this spectral transition (6.4) roughly coincident with those observed in both $k_{\text {cat }}$ and $k_{\text {cat }} / \mathrm{K}_{m}$ profiles strengthens the argument that this ionization is associated with a catalytic event.

There is no evidence to support an assignment of the $\mathrm{pK}$ (7.9) observed on the basic side of the $k_{\text {cat }}$ profile to a specific group. It is likely the same one seen in the $\mathrm{pH}$ profile for $\mathrm{K}_{\mathrm{D} \text { (PLP) }}$ (8.3). Its presence on the $\mathrm{K}_{\mathrm{D} \text { (PLP) }}$ profile could suggest that the phosphate ester of the coenzyme phosphate group is the likely origin of this $\mathrm{pK}$, which has a value similar to that observed for the coenzyme phosphate group in Treponema denticola cystalysin [35]. In hDDC the effect of this ionization could be the loss of the hydrogen bond between the hydroxyl group of Ser149 and the coenzyme phosphate group oxygen. Considering the large conformational change accompanying the transition from the apo to the holo form of hDDC [27], it can be speculated that the loss of hydrogen bond not only decreases the PLP binding affinity but also could hamper a correct apo $\rightarrow$ holo conversion resulting in a less catalytically competent conformation as the $\mathrm{pH}$ increases above 8 . Nonetheless, it cannot be ruled out that the $\mathrm{pK}$ observed in
$\mathrm{K}_{\mathrm{D} \text { (PLP) }}$ does not coincide with the $\mathrm{pK}$ of the $k_{\text {cat }}$ profile. In this case, the effect on the $k_{\text {cat }}$ could be exerted by the ionization of a residue that, although remote from the active site, could affect the active site. A good candidate could be Tyr332 for which a role in $\mathrm{C} \alpha$ protonation of the quinonoid along the decarboxylation pathway has been identified [22]. Although this assignment should be taken with caution, it is not in contrast with the detection at $\mathrm{pH}$ higher than $\mathrm{pK}$ of a $\sim 40 \mathrm{~nm}$ absorbing shoulder attributable to a quinonoid species. Taken together, these results indicate that the maximum $k_{\text {cat }}$ value of hDDC is achieved when the deprotonation of the external aldimine and that of an unidentified residue take place.

In the light of these data, the absence of a band absorbing at $390 \mathrm{~nm}$ in the reaction with L-Dopa of four DDC variants responsible for AADC deficiency, an inherited rare neurometabolic disease, should be reconsidered. In these variants, mutations concerning amino acid residues that interact directly or indirectly with PLP and/or its microenvironment, cause a perturbation of the active site [11]. It can be postulated that in these variants the external aldimine absorbing at $420 \mathrm{~nm}$ is not in a proper position and/or orientation to transfer the proton at $4^{\prime} \mathrm{N}$ of the Schiff base. Taking into account that, according to Minelli et al. [30], the $390 \mathrm{~nm}$ form is about 5 -fold more reactive than the $420 \mathrm{~nm}$ one, it can be speculated that their reduced catalytic activity could be ascribable, at least in part, to the lack of the $420 \rightarrow 390 \mathrm{~nm}$ conversion.

\section{Conclusions}

A detailed investigation of the $\mathrm{pH}$ dependence of the steadystate kinetic parameters, of the spectroscopic titrations of the internal and external aldimine, as well as of the PLP binding affinity allows us to identify three observable ionizations in hDDC. The following tentative assignments for these have been made: $\mathrm{pK}_{1}$ (6.3-6.4), the deprotonation of the $4^{\prime}$-N-protonated external aldimine occurring during the decarboxylation pathway, $\mathrm{pK}_{2}(\sim 7.2)$, a residue governing the equilibrium between the low- and the high-pH forms of the internal aldimine, and $\mathrm{pK}_{3}(7.9,8.3)$, two distinct groups (the coenzyme phosphate ester of the internal aldimine and a residue involved in the catalysis) or a unique residue affecting both PLP binding affinity and $k_{\text {cat }}$ value: additional studies will be needed to sort out the various possibilities.

\section{Abbreviations}

hDDC: Human Dopa decarboxylase

PLP: $\quad$ Pyridoxal $5^{\prime}$-phosphate

AADC: L-Aromatic amino acid decarboxylase

$\mathrm{K}_{\mathrm{D}(\mathrm{PLP})}$ : Equilibrium dissociation constant for PLP.

\section{Acknowledgments}

This work was supported by grants from M.I.U.R and the Consorzio Interuniversitario per le Biotecnologie CIB (IT) to C. B. Voltattorni and B. Cellini. 


\section{References}

[1] A. Amadasi, M. Bertoldi, R. Contestabile et al., "Pyridoxal 5' phosphate enzymes as targets for therapeutic agents," Current Medicinal Chemistry, vol. 14, no. 12, pp. 1291-1324, 2007.

[2] B. Cellini, A. Lorenzetto, R. Montioli, E. Oppici, and C. B. Voltattorni, "Human liver peroxisomal alanine:glyoxylate aminotransferase: different stability under chemical stress of the major allele, the minor allele, and its pathogenic G170R variant," Biochimie, vol. 92, no. 12, pp. 1801-1811, 2010.

[3] B. Cellini, E. Oppici, A. Paiardini, and R. Montioli, "Molecular insights into primary hyperoxaluria type 1 pathogenesis," Frontiers in Bioscience, vol. 17, pp. 621-634, 2012.

[4] M. L. di Salvo, R. Contestabile, A. Paiardini, and B. Maras, "Glycine consumption and mitochondrial serine hydroxymethyltransferase in cancer cells: the heme connection," Medical Hypotheses, vol. 80, pp. 633-636, 2013.

[5] A. E. Pegg, L. M. Shantz, and C. S. Coleman, "Ornithine decarboxylase as a target for chemoprevention," Journal of Cellular Biochemistry, vol. 58, no. 22, pp. 132-138, 1995.

[6] N. A. Rao, R. Talwar, and H. S. Savithri, "Molecular organization, catalytic mechanism and function of serine hydroxymethyltransferase-a potential target for cancer chemotherapy," International Journal of Biochemistry and Cell Biology, vol. 32, no. 4, pp. 405-416, 2000.

[7] P. Storici, G. Capitani, D. De Biase et al., "Crystal structure of GABA-aminotransferase, a target for antiepileptic drug therapy," Biochemistry, vol. 38, no. 27, pp. 8628-8634, 1999.

[8] B. Cellini, R. Montioli, E. Oppici, and C. B. Voltattorni, "Biochemical and computational approaches to improve the clinical treatment of dopa decarboxylase-related diseases: an overview," Open Biochemistry Journal, vol. 6, pp. 131-138, 2012.

[9] F. Daidone, R. Montioli, A. Paiardini et al., "Identification by virtual screening and in vitro testing of human DOPA decarboxylase inhibitors," PLoS ONE, vol. 7, no. 2, Article ID e31610, 2012.

[10] R. Montioli, E. Oppici, B. Cellini, A. Roncador, M. Dindo, and C. B. Voltattorni, "S250F variant associated with aromatic amino acid decarboxylase deficiency: molecular defects and intracellular rescue by pyridoxine," Human Molecular Genetics, vol. 22, no. 8, pp. 1615-1624, 2013.

[11] R. Montioli, B. Cellini, and C. Borri Voltattorni, "Molecular insights into the pathogenicity of variants associated with the aromatic amino acid decarboxylase deficiency," Journal of Inherited Metabolic Disease, vol. 34, pp. 1213-1224, 2011.

[12] B. Maras, P. Dominici, D. Barra, F. Bossa, and C. Borri Voltattorni, "Pig kidney 3,4-dihydroxyphenylalanine (Dopa) decarboxylase. Primary structure and relationships to other amino acid decarboxylases," European Journal of Biochemistry, vol. 201, no. 2, pp. 385-391, 1991.

[13] C. B. Voltattorni, A. Minelli, and P. Dominici, "Interaction of aromatic amino acids in $\mathrm{D}$ and $\mathrm{L}$ forms with 3,4-dihydroxyphenylalanine decarboxylase from pig kidney," Biochemistry, vol. 22, no. 9, pp. 2249-2254, 1983.

[14] C. B. Voltattorni, A. Minelli, and C. Turano, "Spectral properties of the coenzyme bound to DOPA decarboxylase from pig kidney," FEBS Letters, vol. 17, no. 2, pp. 231-235, 1971.

[15] C. B. Voltattorni, A. Minelli, and P. Vecchini, "Purification and characterization of 3,4-dihydroxyphenylalanine decarboxylase from pig kidney," European Journal of Biochemistry, vol. 93, no. 1, pp. 181-187, 1979.
[16] P. Dominici, B. Tancini, D. Barra, and C. B. Voltattorni, "Purification and characterization of rat-liver 3,4-dihydroxyphenylalanine decarboxylase," European Journal of Biochemistry, vol. 169, no. 1, pp. 209-213, 1987.

[17] A. Fiori, C. Turano, and C. Borri Voltattorni, "Interaction of L DOPA decarboxylase with substrates. A spectrophotometric study," FEBS Letters, vol. 54, no. 2, pp. 122-125, 1975.

[18] M. Bertoldi and C. Borri Voltattorni, "Reaction of dopa decarboxylase with L-aromatic amino acids under aerobic and anaerobic conditions," Biochemical Journal, vol. 352, no. 2, pp. 533-538, 2000

[19] M. Bertoldi, B. Cellini, B. Maras, and C. B. Voltattorni, "A quinonoid is an intermediate of oxidative deamination reaction catalyzed by Dopa decarboxylase," FEBS Letters, vol. 579, no. 23, pp. 5175-5180, 2005.

[20] M. Bertoldi, B. Cellini, R. Montioli, and C. B. Voltattorni, "Insights into the mechanism of oxidative deamination catalyzed by DOPA decarboxylase," Biochemistry, vol. 47, no. 27, pp. 7187-7195, 2008.

[21] M. Bertoldi, P. Frigeri, M. Paci, and C. B. Voltattorni, "Reaction specificity of native and nicked 3,4-dihydroxyphenylalanine decarboxylase," Journal of Biological Chemistry, vol. 274, no. 9, pp. 5514-5521, 1999.

[22] M. Bertoldi, M. Gonsalvi, R. Contestabile, and C. B. Voltattorni, "Mutation of tyrosine 332 to phenylalanine converts dopa decarboxylase into a decarboxylation-dependent oxidative deaminase," Journal of Biological Chemistry, vol. 277, no. 39, pp. 36357-36362, 2002.

[23] P. Dominici, P. S. Moore, S. Castellani, M. Bertoldi, and C. B. Voltattorni, "Mutation of cysteine 111 in Dopa decarboxylase leads to active site perturbation," Protein Science, vol. 6, no. 9, pp. 2007-2015, 1997.

[24] P. S. Moore, P. Dominici, and C. Borri Voltattorni, "Cloning and expression of pig kidney dopa decarboxylase: comparison of the naturally occurring and recombinant enzymes," Biochemical Journal, vol. 315, no. 1, pp. 249-256, 1996.

[25] H. Hayashi, H. Mizuguchi, and H. Kagamiyama, "Rat liver aromatic L-amino acid decarboxylase: spectroscopic and kinetic analysis of the coenzyme and reaction intermediates," Biochemistry, vol. 32, no. 3, pp. 812-818, 1993.

[26] H. Hayashi, F. Tsukiyama, S. Ishii, H. Mizuguchi, and H. Kagamiyama, "Acid base chemistry of the reaction of aromatic L-amino acid decarboxylase and dopa analyzed by transient and steady-state kinetics: preferential binding of the substrate with its amino group unprotonated," Biochemistry, vol. 38, no. 47, pp. 15615-15622, 1999.

[27] G. Giardina, R. Montioli, S. Gianni et al., "Open conformation of human DOPA decarboxylase reveals the mechanism of PLP addition to Group II decarboxylases," Proceedings of the National Academy of Sciences of the United States of America, vol. 108, no. 51, pp. 20514-20519, 2011.

[28] P. Burkhard, P. Dominici, C. Borri-Voltattorni, J. N. Jansonius, and V. N. Malashkevich, "Structural insight into Parkinson's disease treatment from drug-inhibited DOPA decarboxylase," Nature Structural Biology, vol. 8, no. 11, pp. 963-967, 2001.

[29] R. Singh, F. Spyrakis, P. Cozzini, A. Paiardini, S. Pascarella, and A. Mozzarelli, "Chemogenomics of pyridoxal 5' -phosphate dependent enzymes," Journal of Enzyme Inhibition and Medicinal Chemistry, vol. 28, no. 1, pp. 183-194, 2013. 
[30] A. Minelli, A. T. Charteris, C. B. Voltattorni, and R. A. John, "Reactions of DOPA (3,4-dihydroxyphenylalanine) decarboxylase with DOPA," Biochemical Journal, vol. 183, no. 2, pp. 361368, 1979.

[31] A. F. Sherald, J. C. Sparrow, and T. R. F. Wright, "A spectrophotometric assay for Drosophila dopa decarboxylase," Analytical Biochemistry, vol. 56, no. 1, pp. 300-305, 1973.

[32] A. Charteris and R. John, "An investigation of the assay of dopamine using trinitrobenzensulphonic acid," Analytical Biochemistry, vol. 66, no. 2, pp. 365-371, 1975.

[33] C. M. Metzler, A. G. Harris, and D. E. Metzler, "Spectroscopic studies of quinonoid species from pyridoxal 5'-phosphate," Biochemistry, vol. 27, no. 13, pp. 4923-4933, 1988.

[34] M. Bertoldi and C. B. Voltattorni, "Multiple roles of the active site lysine of Dopa decarboxylase," Archives of Biochemistry and Biophysics, vol. 488, no. 2, pp. 130-139, 2009.

[35] B. Cellini, M. Bertoldi, R. Montioli, and C. B. Voltattorni, "Probing the role of Tyr 64 of Treponema denticola cystalysin by site-directed mutagenesis and kinetic studies," Biochemistry, vol. 44, no. 42, pp. 13970-13980, 2005.

[36] G. A. Hunter, J. Zhang, and G. C. Ferreira, "Transient kinetic studies support refinements to the chemical and kinetic mechanisms of aminolevulinate synthase," Journal of Biological Chemistry, vol. 282, no. 32, pp. 23025-23035, 2007.

[37] X. Zhou and M. D. Toney, "pH Studies on the mechanism of the pyridoxal phosphate-dependent dialkylglycine decarboxylase," Biochemistry, vol. 38, no. 1, pp. 311-320, 1999.

[38] W. E. Karsten, T. Ohshiro, Y. Izumi, and P. F. Cook, "Initial velocity, spectral, and $\mathrm{pH}$ studies of the serine-glyoxylate aminotransferase from Hyphomicrobiuim methylovorum," Archives of Biochemistry and Biophysics, vol. 388, no. 2, pp. 267-275, 2001.

[39] D. M. Kiick and P. F. Cook, "pH studies toward the elucidation of the auxiliary catalyst for pig heart aspartate aminotransferase," Biochemistry, vol. 22, no. 2, pp. 375-382, 1983.

[40] K. O. Honikel and N. B. Madsen, "Comparison of the absorbance spectra and fluorescence behavior of phosphorylase $b$ with that of model pyridoxal phosphate derivatives in various solvents," Journal of Biological Chemistry, vol. 247, no. 4, pp. 1057-1064, 1972.

[41] M. T. Olmo, F. Sánchez-Jiménez, M. A. Medina, and H. Hayashi, "Spectroscopic analysis of recombinant rat histidine decarboxylase," Journal of Biochemistry, vol. 132, no. 3, pp. 433-439, 2002.

[42] W. C. Chu and D. E. Metzler, "Enzymatically active truncated cat brain glutamate decarboxylase: expression, purification, and absorption spectrum," Archives of Biochemistry and Biophysics, vol. 313, no. 2, pp. 287-295, 1994. 

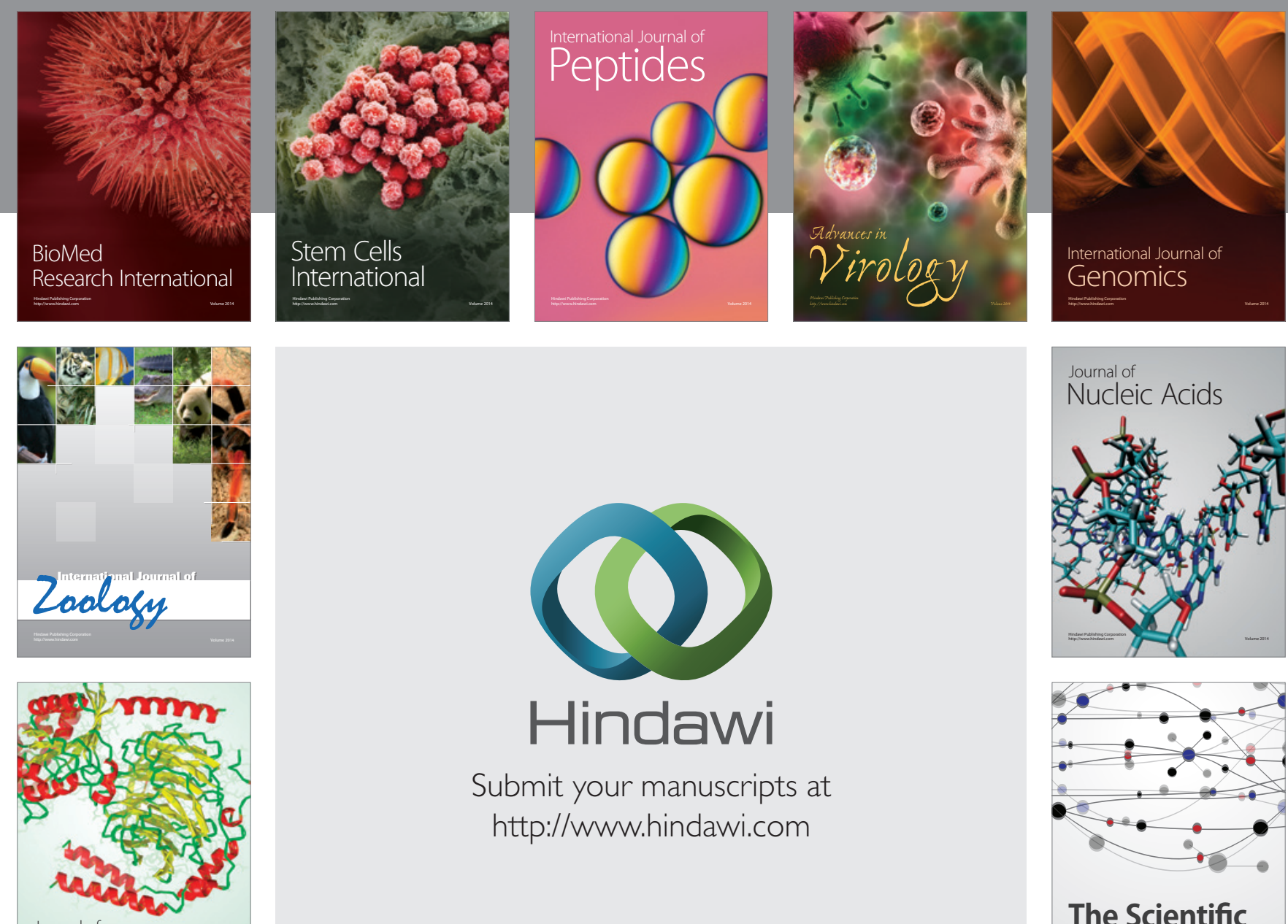

Submit your manuscripts at

http://www.hindawi.com

Journal of
Signal Transduction
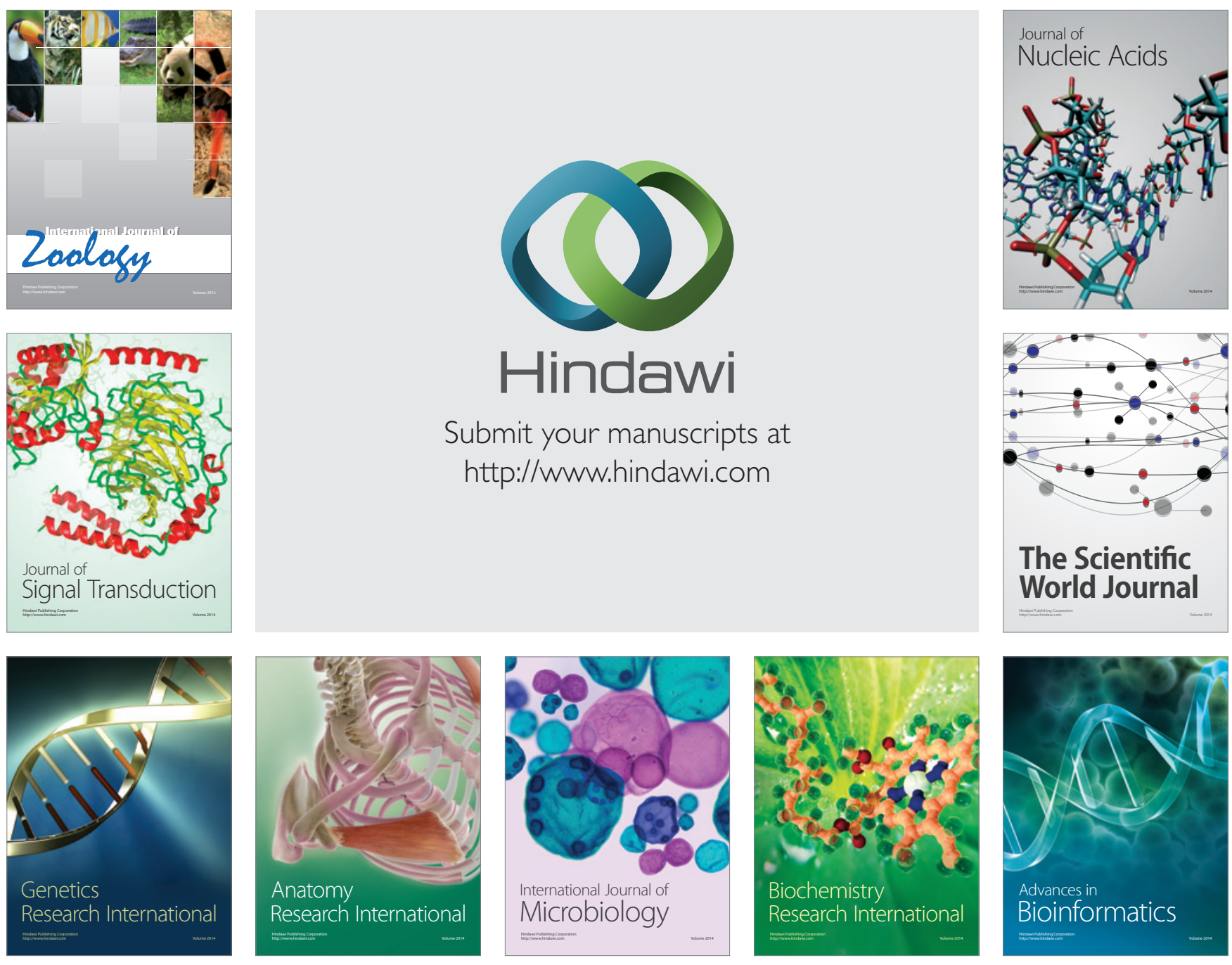

The Scientific World Journal
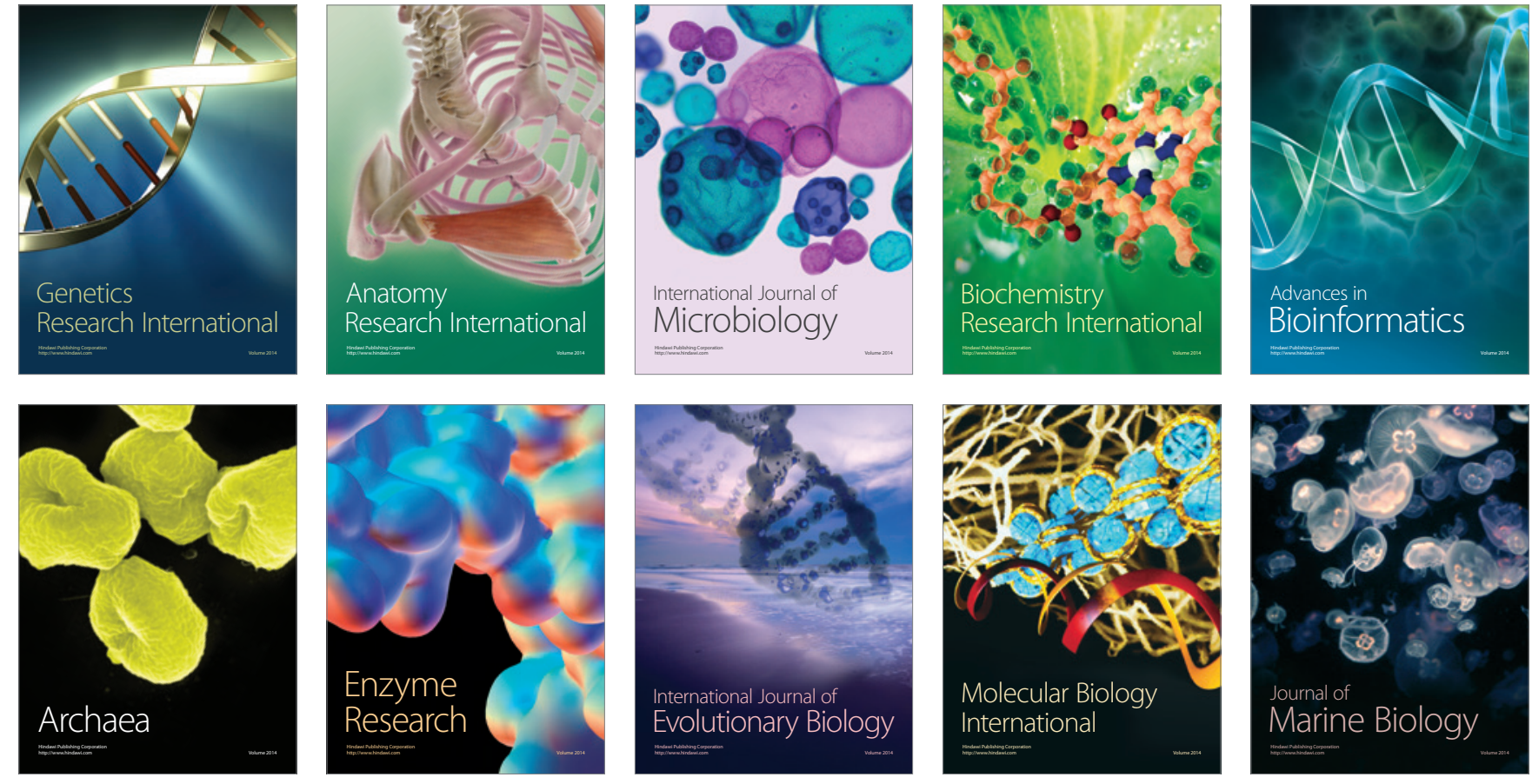